\title{
Tendencies of Poecilus Cupreus Morphometric Alteration Depending on Habitation Region
}

\author{
Sukhodolskaya R.A. \\ Institute of Ecology and Subsoil Use \\ Academy of Sciences of the Republic of Tatarstan \\ Kazan, Russia \\ sukhodolskayaraisa@gmail.com \\ Brigadirenko V.V. \\ Department of Zoology and Ecology \\ Dnieper National University \\ named after Olesya Gonchara \\ Dnipro, Ukraine
}

\author{
Avtaeva T.A. \\ Department of Biological Research \\ Integrated Research Institute \\ them. H.I. Ibragimova RAS \\ Grozny, Russia \\ avtaeva1971@mail.ru \\ brigad@ua.fm
}

Antsiferov A.L.

Kostroma Museum of Nature

Kostroma, Russia

ancifer.ost@yandex.ru

\author{
Kushaliev Sh.A. \\ Department of Biology and its teaching methods \\ Chechen State Pedagogical University \\ Grozny, Russia \\ hemiptera2013@mail.ru
}

\begin{abstract}
The article presents the changes in physical dimensions of Poecilus cupreus under the influence of various ecological factors. The field data comprising 7 habitats of 4 regions (Tatarstan, Ukraine, Chechen Republic, Kostroma region) was gathered. The morphometric study comprised 6 measuring criteria while body size is one of the most significant morphological characters linked with the ontogenesis length, motion activity, reproductive rate, competition capacity. Poecilus cupreus' sizes are stipulated by horizontal zonality and altitudinal zonation. Size alteration is caused by the period of resource availability, i.e. the length of growing season. A shorter season in higher latitudes and high-mountain restricts the period appropriate for feeding, growth and development, and, consequently, for the maximum body size. The body size and form are determined by a set of factors. The most important factors are, apparently, the bugs' wintering area, microclimatic habitat conditions and food availability. The discriminative analysis has revealed that the population composition of $P$. Cupreus statistically differs in all regions. The most alike are the populations of Chechen Republic and Kostroma region, which is due to the certain similarity of altitudinal and latitudinal belts. Presumably, the length of the vegetation period in highmountain is identical to the one in northern latitude. Reportedly, the most different from all are the bugs from Tatarstan. The ground beetles agrocenoses are characterized by a significant difference in the width of the elytra and pronotum. It can be due to the living environment when certain body proportions help to find the appropriate habitats in certain agricultural plants.
\end{abstract}

Keywords - morphometric study, Poecilus cupreus, food potential, microclimatic habitat conditions, Ukraine, Chechen Republic, Tatarstan, Kostroma region, horizontal zonality, altitudinal zonation

\section{INTRODUCTION}

Polymorphism and the consequent morphologic variety are the fundamental properties of living organisms' population.

Morphologic structures and their alteration under the conditions of various factors clarify the processes of organisms' adaptation to the environment and the formation of intrapopulational relationships [11]. Ecological and morphological approach enables to find out intra- and interpopulation relationships which cannot be identified by the other methods and verified experimentally [8]. The body size is one of the most significant morphologic factors dependent on the ontogenesis length, motion activity, reproductive rate, competition capacity.

Study of body size alteration assists in realizing the processes of organisms' adaptation to the environment. Wherefore, several authors have devoted their works to studying the tendencies of body size changing among insects. The most studied in this regard are the beetles of the ground beetles family $[1,2,3,4,5,6,8,9]$. The subject of our research is the alterability of one type ground beetles, namely Poecilus cupreus. 


\section{METHODS AND MATERIALS}

Poecilus cupreus is a palaearctic species with a wide area and is dominant in various agrocoenosis. It is a meadow field species, polyphagous invader with a very strong nutritional adaptation [10].

1).

The material for research was obtained from 7 areas (Table
The bugs were captured using a standard method of pitfall traps during the growing seasons 2016 - 2017. 20 traps were set in each biotype at the distance of $10 \mathrm{~m}$. Bugs were selected once a decade.

TABLE I. DISCRIPTION OF THE CAPTURE AREAS

\begin{tabular}{|c|c|c|c|}
\hline Area & Capture area & Habitat & Number of species \\
\hline $\begin{array}{l}\text { Republic of Tatarstan } 55^{\circ} \text { north } \\
\text { latitude } 49^{0} \text { east longitude }\end{array}$ & $\begin{array}{l}\text { 1. Agrocoenosis of Arsky District } \\
56.2249 .83 \\
\text { 2.Tetyushi region } \\
54.9348 .81\end{array}$ & Rye, wheat, barley & 1200 \\
\hline \multirow{3}{*}{$\begin{array}{l}\text { Chechen Republic } 430 \text { north } \\
\text { latitude } 450 \text { east longitude }\end{array}$} & $\begin{array}{l}\text { 1.Steep slope with slides at an altitude } \\
\text { of } 2000 \mathrm{~m} \text { near Sharoy settlement }\end{array}$ & $\begin{array}{c}\text { prairie June grass, woolly andropogon, Volga } \\
\text { fescue, needle-and-thread grassneedle-and-thread } \\
\text { grass }\end{array}$ & 982 \\
\hline & $\begin{array}{l}\text { 2. Inundable alder wood at an altitude } \\
\text { of } 601 \mathrm{~m} \text { near Tevzan settlement } 42.94 \\
45.41\end{array}$ & $\begin{array}{c}\text { European alder, European filbert, common maple, } \\
\text { European ash }\end{array}$ & 467 \\
\hline & $\begin{array}{l}\text { 3. Mixed herbs gramineous slope of } \\
\text { the Black mountains at an altitude of } \\
700 \mathrm{~m} \text { near Roschny-Chu settlement } \\
42.9845 .90\end{array}$ & Mixed herbs predominantly gramineous & 583 \\
\hline $\begin{array}{l}\text { Ukraine, } \\
48^{0} \text { north latitude } 34^{0} \text { east } \\
\text { longitude }\end{array}$ & $\begin{array}{l}\text { Pavlograd outskirts } \\
48.43 \quad 35.95\end{array}$ & $\begin{array}{c}\text { The third solonetz-solonchak terrace, river Volcha } \\
\text { Broad-leaved cattail, narrow-leaved catoptric, } \\
\text { greater bindweed }\end{array}$ & 430 \\
\hline $\begin{array}{l}\text { Kostroma region } 570 \text { north } \\
\text { latitude } 400 \text { east longitude }\end{array}$ & $\begin{array}{l}\text { Sudislavski region, Village Kalinky } \\
57.7941 .30\end{array}$ & $\begin{array}{l}\text { Three-year cutting down of a fir-tree; willowherb } \\
\text { and raspberry-yard vegetation type with medium } \\
\text { graining and thick grass canopy }\end{array}$ & 378 \\
\hline
\end{tabular}

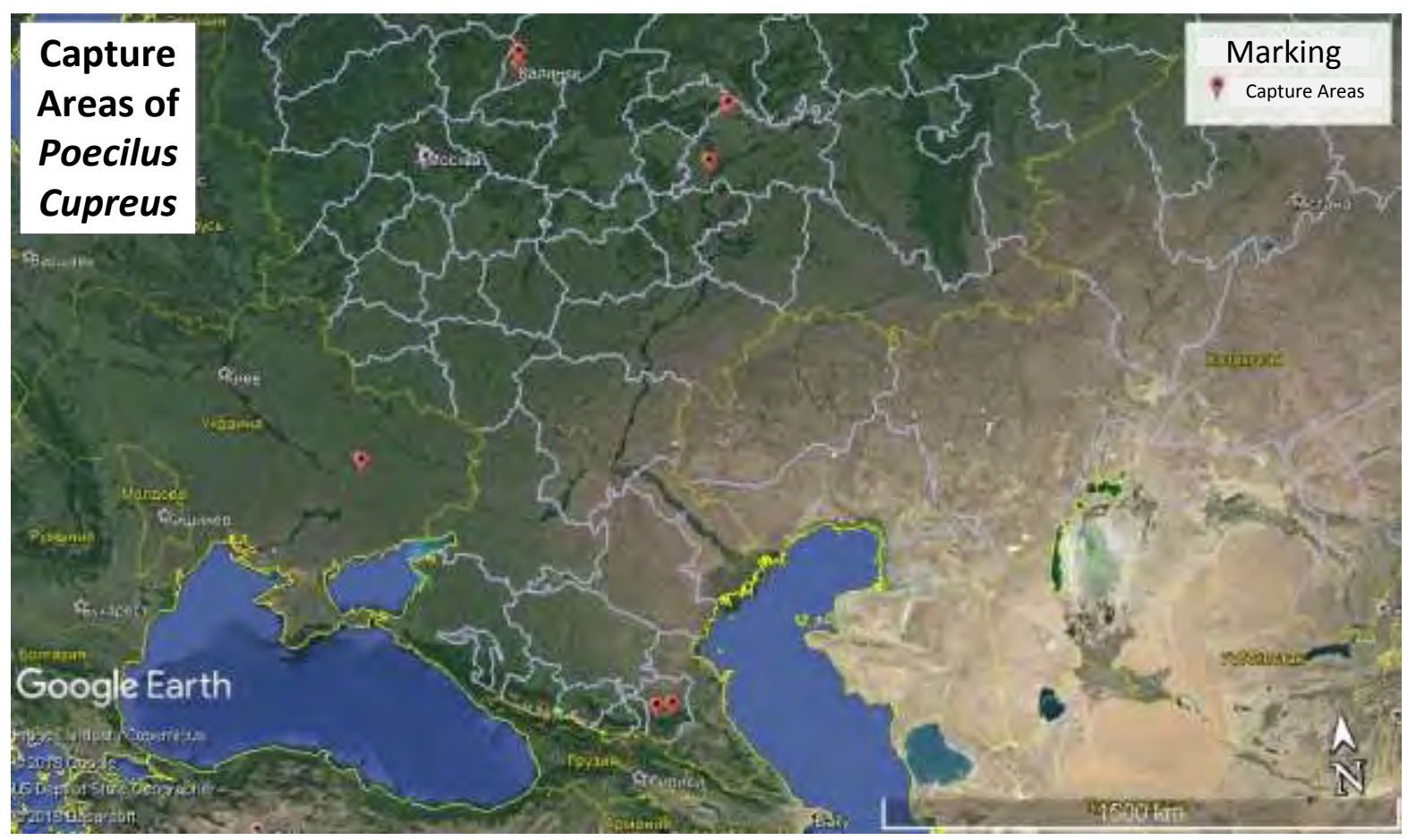

Fig. 1. Red marking on the map denotes the Poecilus cupreus capture areas 


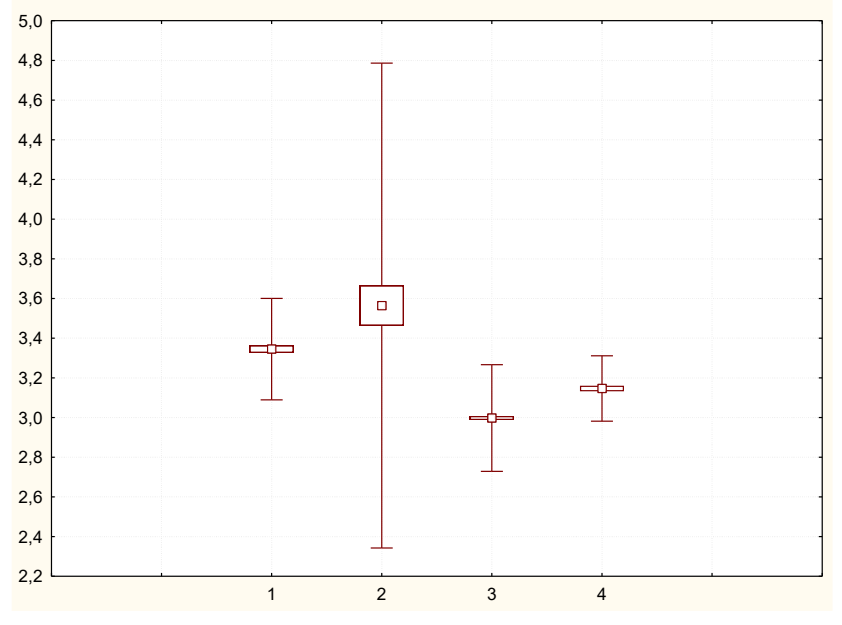

Pronotum width

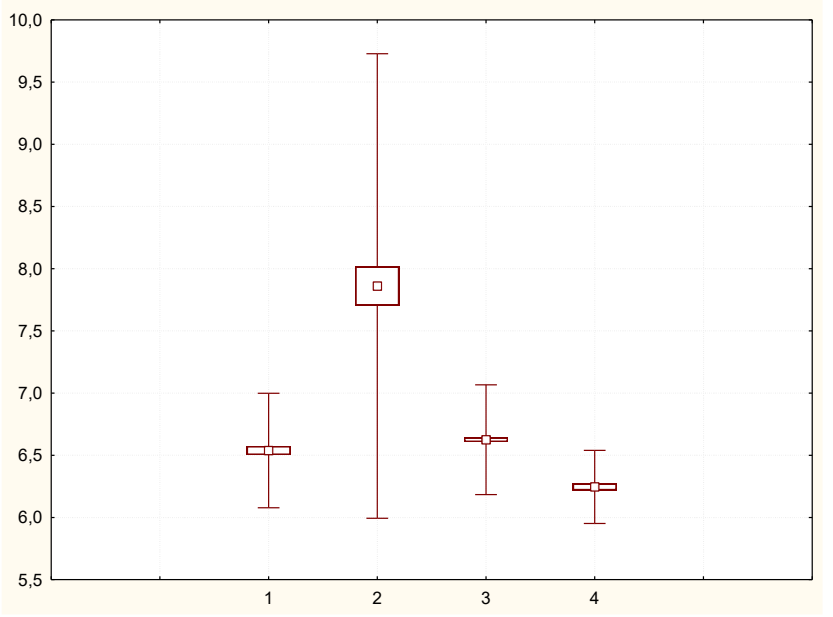

Elytra length

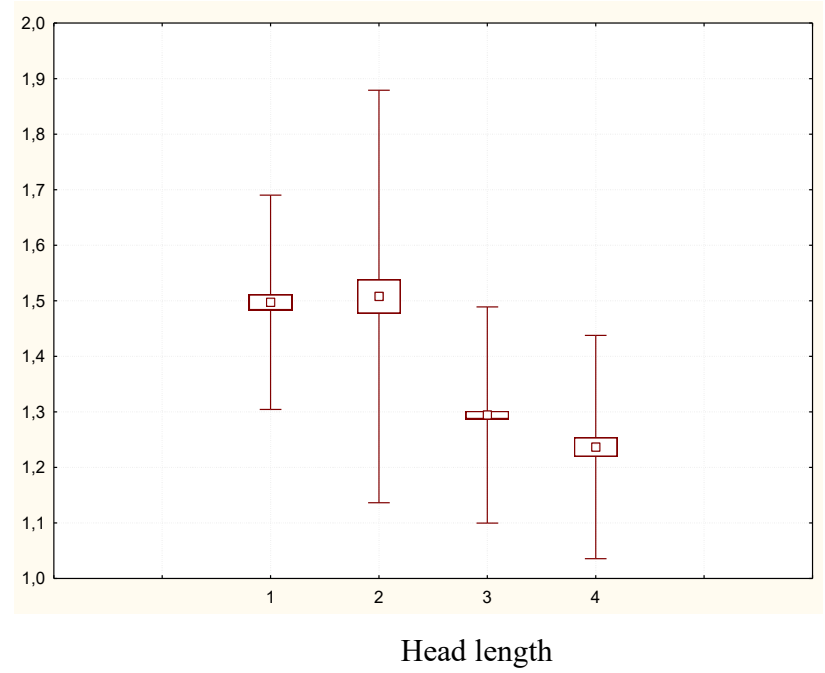

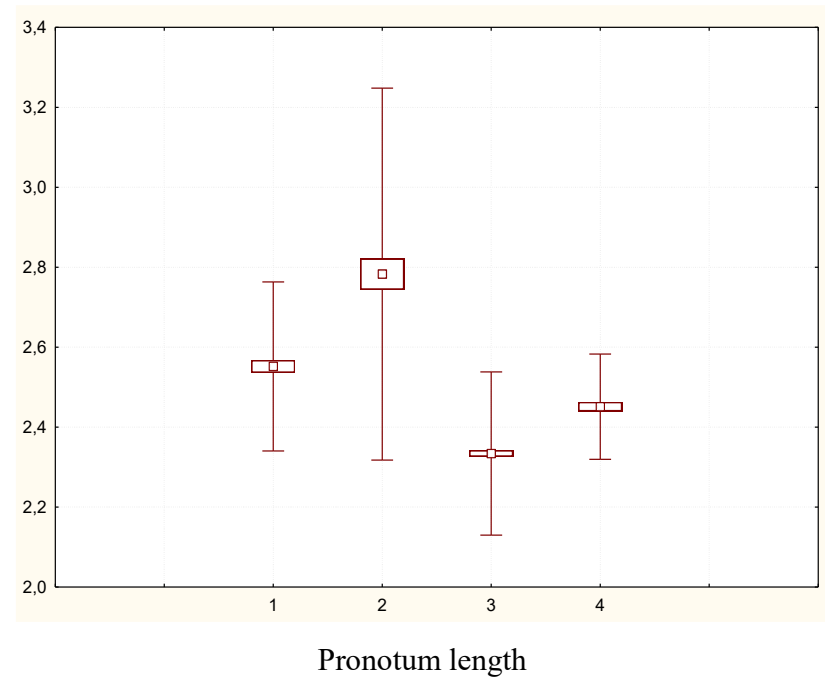

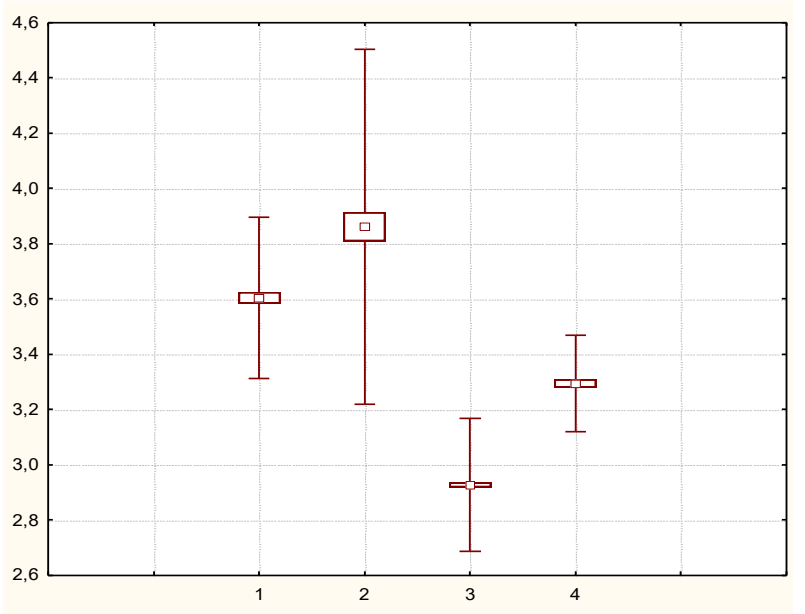

Elytra width

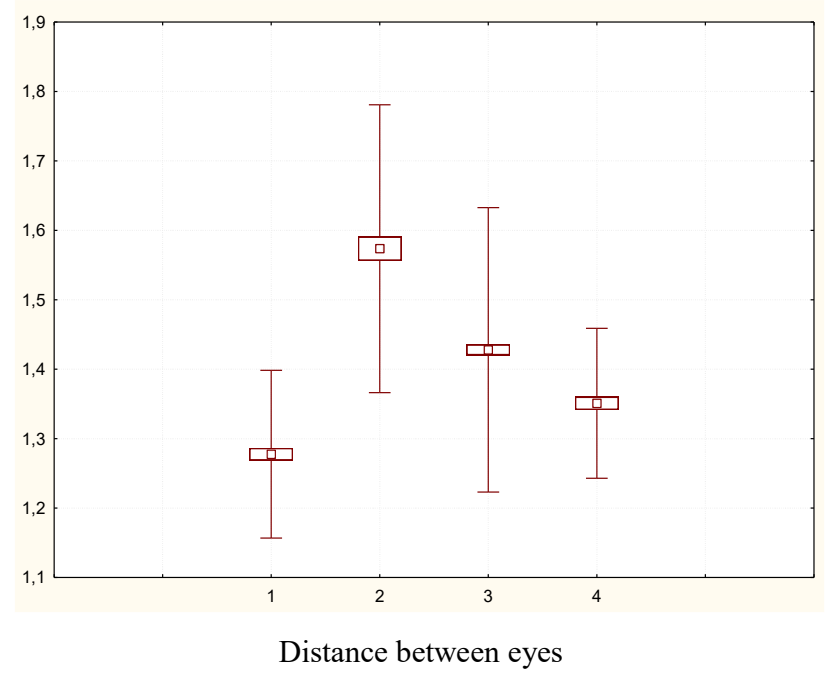

Fig. 2. Variability of measuring characteristics among the P. cupreus. Labelling (here and further): 1 - Chechen Republic, 2 - Ukraine, Dnipropetrovsk oblast, 3 - Republic of Tatarstan, 4 - Kostroma region. 
The morphometric study was carried out with regards to 6 measuring criteria being as follows: length and width of elytra, length and width of pronotum, length and width of head. Statistical processing of material was implemented with the application of Microsoft Excel-97 and Statistica 6.0. The morphometric measuring was made with the use of "Manual Carabid morphometric measurement for the method by Sukhodolskaya" developed according to R.A. Sukhodolskaya methods.

\section{RESULTS}

The visualization of geographic $P$. cupreus capture areas demonstrates that the areas under research are situated from the South to the North: Chechen Republic, Ukraine, Republic of Tatarstan, Kostroma region. Figure 2 presents the descriptive statistics of the $P$. cupreus examined characteristics.

As it is seen in the presented pictures (Figure 2), the size of $P$. cupreus gradually descends from the South to the North. However, the bugs of the area which is the closest to the South (Chechen Republic) are smaller than the bugs captures in Ukraine. The Poecilus cupreus of Chechen Republic are characterized by monovoltine spring-and-summer recyclic type of life cycle. Three activity peaks (in the middle of April, in May and in August) are distinguished [7]. According to the Roff model [Roff, 1980] the monovoltine (one geniture per year) organisms' size reduces with regards to latitude and altitude while there is less time available for the growth and development. Size reduction is usually linked with resource limitation namely the period of resources availability stipulated by the season length. A shorter period in higher latitudes and high-mountains limits the time appropriate for feeding, growth and development and, consequently, the size of the body which can be achieved. The P. cupreus capture area in Chechen Republic belongs to the category of mountain terrain what accounts for a smaller bugs' size in comparison with Ukraine.

The size and form of the body are determined by a set of factors the most significant of which are, apparently, bugs wintering areas, microclimatic habitat conditions and food supply. Soil excavations were carried out with the objective to determine the wintering areas. It was stated that Poecilus cupreus imago winter in beddings, topsoil, and tree plantations. The spring activity peak in timber area is stipulated by the bags mass leaving wintering area and searching a take in closest habitats. The population peak in August is attributed to a good trophic base being larvae and imagoes of small insects accumulated in top humus. This may explain bigger bugs captured in alder wood in comparison with the ones in steppe slopes in Chechen Republic.

Biotope near Pavlograd (Ukraine) is reed mace brushing with $85 \%$ of herbaceous layer. The bedding is $10 \mathrm{~cm}$ thick and is made of reed mace rootstock. Coastal water plants are not only a food constituent for organisms but also a habitat. Some insects use vegetation beds for egg deposition, feeding larvae and as shelter. Thus, a beneficial food potential is made for zoophages such as Poecilus cupreus. Apparently, larger bugs of this biotope are linked with the food potential.

There is a significant reduction in the elytra and pronotum width among ground beetles agrocenoses. It can possibly be stipulated by the living environment when certain body proportions help to find suitable habitats in certain agricultural plant [9]. Herewith, the elytra length increases in agrocoenoses, which is confirmed by the data obtained in Tatarstan.

Poecilus cupreus imagos inhabiting the three-year cutting down of a fir-tree are characterized by smaller sizes with regards to all 6 measuring criteria. Both antropogenic factor linked with the secondary seral processes and environment conditions in more northern latitudes can exert the influence.

The discriminative analysis has shown that $P$. cupreus population composition is statistically dissimilar in all regions (Figure 3). The most alike are the populations from Chechen Republic and Kostroma region, which is due to the similarity of altitudinal and latitudinal belts. Possibly, the length of the vegetation period in the high-mountains is identical to the one in northern latitudes. According to the obtained data the bugs from Tatarstan are the most different from all the populations (Table 1).

It is fair to assume that the shift of regions under research eastwards also has certain influence on the sizes. Some researchers studying dragonflies state the species sizes reduction towards the east.

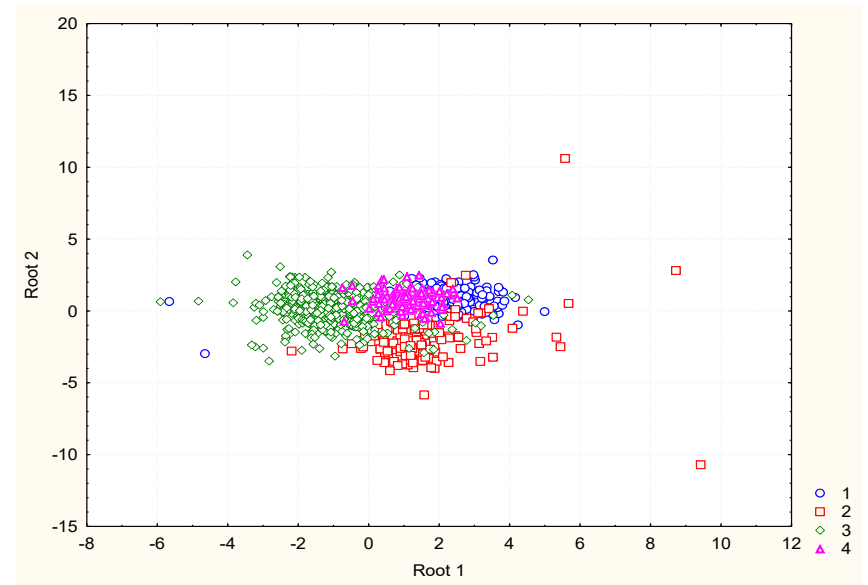

Fig. 3. P. cupreus population exposition in the plane of two discriminant functions (Wilks' Lambda: 1998885 approx. F (18.3547) $=151.1336 \mathrm{p}<0.0000)$

TABLE II. DISTANCE SQUARE OF MAHALANOBIS BETWEEN THE CENTROIDS OF THE CHARACTERISTICS DISTRIBUTION OF SAMPLINGS

\begin{tabular}{|l|c|c|c|c|}
\hline & $\mathbf{1}$ & $\mathbf{2}$ & $\mathbf{3}$ & $\mathbf{4}$ \\
\hline $\mathbf{1}$ & 0.00000 & 8.39430 & 11.72846 & 2.632404 \\
\hline $\mathbf{2}$ & 8.39430 & 0.00000 & 10.87296 & 8.038554 \\
\hline $\mathbf{3}$ & 11.72846 & 10.87296 & 0.00000 & 5.772192 \\
\hline $\mathbf{4}$ & $\mathbf{2 . 6 3 2 4 0}$ & 8.03855 & 5.77219 & 0.000000 \\
\hline
\end{tabular}

The research results are presented in Figure 4. 


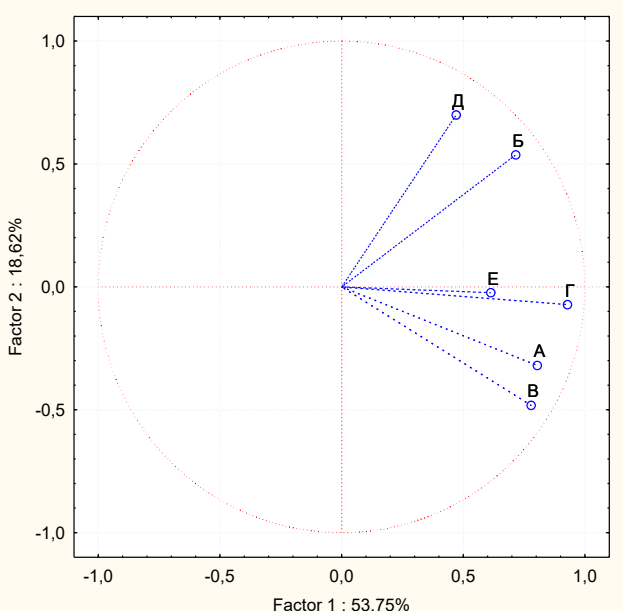

Chechen Republic

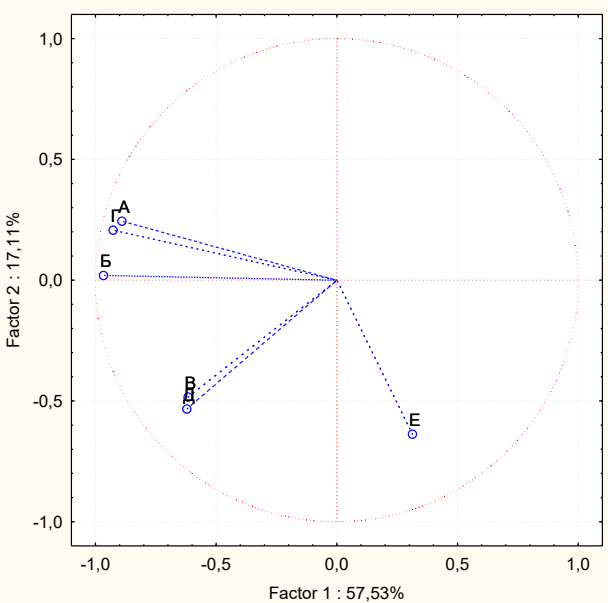

Ukraine

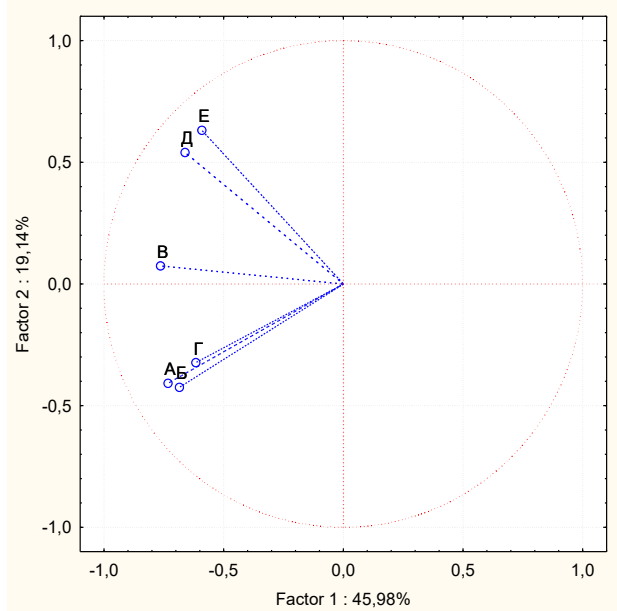

Republic of Tatarstan

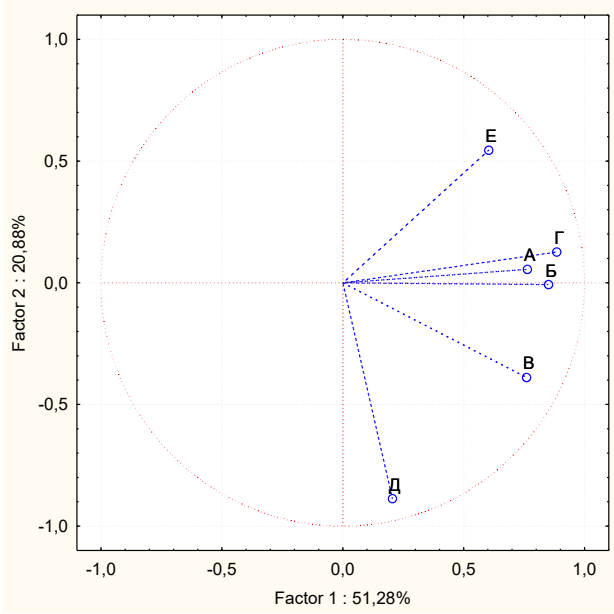

Kostroma region

Fig. 4. Results if the research

\section{Research outcomes:}

1. All samplings are structured rather well while the sum of two main components is always more than $50 \%$.

2. In all samplings the major load with regards to the fist factor is posed on factors A, B, C, D (i.e. elytra and promotum), to the second one is posed on the factors of head (apart from Tatarstan). It can possibly be due to the increase of searching activity.

\section{CONCLUSION}

The sizes of Poecilus cupreus depend on horizontal zonality and altitudinal zonation. Dependence on the biotope type and the content of food potential cannot be excluded. Thick bedding, where a lot of small organisms live, creates a good food potential, which influences the size of bugs. In contrast, resource limitation and the reduction of their availability period cause size reduction. A shorter season in higher latitudes and high-mountains shortens the period suitable for feeding, growth and development and, consequently, the body size possible to achieve. It is stated that the body size is influenced by such factors as bugs wintering areas, microclimatic habitat conditions and food availability.

According to the outcomes of the discriminative analysis the $P$. Cupreus population structure is statistically dissimilar in all regions. The most alike populations are in Chechen Republic and Kostroma region. It is possible that the length of vegetation period is identical to the one of northern latitudes.

According to the data obtained, the most different of all are the bugs from Tatarstan. The significant reduction of elytra and promotum width is noticed among ground beetles agrocenoses. It can be due to the living environment when certain body proportions help to find suitable habitats in certain agricultural plants.

\section{References}

[1] D. Y. Reshetniak, O. Y. Pakhomov, V. V. Brygadyrenko, "Possibility of identifying plant components of the diet of Harpalus rufipes (Coleoptera, 
Carabidae) by visual evaluation", Regulatory Mechanisms in Biosystems, vol. 8(3), pp. 377-383, 2017

[2] R.A. Sukhodolskaya, A.A. Saveliev, "Body Size Variation of Ground Beetles (Coleoptera: Carabidae) in Latitudinal Gradient", Periodicum biologorum vol. 118, no 3, pp. 273-280, 2016 doi: 10.18054/pb.2016.118.3.3918

[3] R.A. Sukhodolskaya, A.A. Saveliev, "Crop impact on body size variation in carabid beetlen Poecilus cupreus Linnaeus (Coleoptera, Carabidae)", Ukrainska Entomofaunistyka, vol.3, no. 7, pp. 85-91, 2016.

[4] V. V. Brygadyrenko, "Community structure of litter invertebrates of forest belt ecosystems in the Ukrainian steppe zone", International Journal of Environmental Research, vol. 9(4), 2015, pp. 1183-1192.

[5] V. V. Brygadyrenko, "Evaluation of ecological niches of abundant species of Poecilus and Pterostichus (Coleoptera: Carabidae) in forests of the steppe zone of Ukraine", Entomologica Fennica, vol. 27, pp. 81100, 2016.

[6] V. V.Brygadyrenko, O. V. Korolev, "Morphological polymorphism in an urban populatiom of Pterostichus melanarius (Illiger, 1798) (Coleoptera, Carabidae)", Graellsia, vol. 71(1), pp. 21-25, 2015
[7] T.A. Avtaeva, Sh.A. Kushaliyeva, "On the ecology of Poecilus cupreus L.1758 in the conditions of the Chechen Republic", XVth Congress of the Russian Entomological Society: Abstracts, Novosibirsk, JulyAugust, 2017

[8] D.B. Gelashvili, D.I. Iudin., M.S. Snegireva et al., "Fractal analysis of the species structure of karabid complexes of urbanized territories (using the example of Kazan)", Volga ecological journal, vol. 4, pp. 407-420, 2011 .

[9] N.P. Khabibullina, R.A. Sukhodolskaya, "Ecological and faunistic overview of the population of ground beetles (Coleoptera, Carabidae) of agrocenoses of the Republic of Tatarstan”, Zoological research in the regions of Russia and adjacent territories: materials of the International Scientific Conference, Saransk: Progress Printing House, pp. 108-110, 2010 .

[10] O.G.Guseva, A.G. Koval, "Food connections of ground beetles Pterostichus melanarius and Poecilus cupreus (Coleoptera, Carabidae)", Vestnik zashchity rasteniy, vol. 1, pp. 61-63, 2010

[11] W. L. Gannon and G. R. Racz, "Character displacement and ecomorphological analysis of two long-eared Myotis (M. auriculus and M. evotis)", Journal of Mammalogy, vol. 87(1), 2006, pp.171-179. 